\title{
Contribution to the diversity of soil mites (Acari, Gamasida) in southern Croatia (Dalmatia), with some ecological and zoogeographical notes
}

\author{
SŁAWOMIR KACZMAREK and TOMASZ MARQUARDT \\ Kazimierz Wielki University, Institute of Environmental Biology, Department of Zoology, \\ Ossolińskich 12, PL 85-094 Bydgoszcz, Poland \\ Corresponding author: Sławomir Kaczmarek, slawkacz@ukw.edu.pl
}

(Received on 16 January 2008; Accepted on 31 March 2010)

\begin{abstract}
The species diversity of soil gamasid mites (Acari) in southern Croatia (Dalmatia) was studied in August 2002. In the Krka National Park, Brač Island, and near the town of Makarska, 320 samples were collected from various microhabitats: soil, grass and moss ground cover, wet moss, needle litter, moss covering tree trunks, and decaying wood). Altogether, 2097 mites of 56 gamasid species were recorded. Dominant species were: Polyaspis patavinus (Brač Island), Zercon fageticola (Makarska), and Cheiroseius serratus (Krka National Park). Analyses of ecological preferences and zoogeographic distribution were made for Polyaspis patavinus, Cheiroseius serratus, Zercon fageticola, Z. berlesei, Z. athiasi, Asca nova and $A$. aphidioides.
\end{abstract}

Keywords: Gamasida, Acari, Croatia, biodiversity, zoogeography

\section{INTRODUCTION}

The Balkan Peninsula is located at the border of 2 regions of the Holarctic zone: Euro-Siberian and Mediterranean. Therefore, it could be expected that this is an area of interactions between faunas of both zoogeographical regions. Croatia, a country with a relatively small area, as a result of its location as well as its landscape and diversified climate, is distinguished by a mosaic of microhabitats, which favours high species diversity. So far, research on the acarofauna of Croatia has been limited to Oribatida, Hydrachnidia and Uropodina (HIRSCHMANN \& WIŚNIEWSKI 1993; RUCNER \& RUCNER 1995; PESIC 2002). That is why the present study was aimed to investigate the species diversity of Gamasida in Croatia.

\section{STUDY AREA}

The Republic of Croatia is located in the south of Central Europe and has a long coastline on the Adriatic Sea. The area of the country is $56594 \mathrm{~km}^{2}$. Its coastline is 
$5835 \mathrm{~km}$ long, but $4058 \mathrm{~km}$ (almost 70\%) is constituted by islands. The south-west of the country is mostly covered by the Dinaric Alps. Dalmatia is the southwestern part of Croatia and was formed as a result of the Adriatic flooding some mountain chains, which created a unique landscape with islands and peninsulas oriented parallel to the coastline. In contrast, the northeastern part of the country is a fragment of the Pannonian Basin (= Great Hungarian Plain).

Despite its relatively small area, Croatia is distinguished by a quite diversified climate. It is Mediterranean along the coastline, but the area covered by mountain chains is characterised by a much cooler climate, while the northeast of the country has a continental climate.

The flora of Croatia is as diversified as its climate. The coast is covered with evergreen forests and thorny Mediterranean bushes. Coniferous trees prevail in the mountains, while the lowland remains practically forestless (except for Slavonia, where oak forests have survived).

\section{MATERIAL AND METHODS}

Altogether 320 samples (50 $\mathrm{cm}^{3}$ each) were collected on 24-28 August 2002 from various microhabitats (moss covering soil, stones and tree trunks, as well as decaying wood and litter), from 40 plots in the Krka National Park (93 samples), on Brač Island (94 samples), and near the town of Makarska (133 samples). In total, 2097 mites were extracted by using modified Tullgren funnels for 6 days, preserved in $70 \%$ ethyl alcohol, and finally mounted in Hoyer's medium. Gamasid mites, both mature and immature, were identified to species level using the keys of BŁASZAK (1974), Bregetova et al. (1977), KARg (1993) and MašÁn \& Fenda (2004).

The zoocoenological analysis was based on several indicators: the number of individuals, dominance, constancy, number of species, and the Shannon index of diversity. Additionally, a zoogeographical analysis of Polyaspis patavinus, Cheiroseius serratus, Zercon fageticola, Z. berlesei, Z. athiasi as well as Asca nova and A. aphidioides was performed based on available literature.

\section{RESULTS}

Overall, 56 species of the Gamasida, belonging to 32 genera, were recorded within the study area (Table 1). The genus Hypoaspis was represented by 8 species, while the genera Pergamasus, Veigaia and Zercon, by 3 species each. The number of species reached 25 in Brač Island and Makarska each, and 33 in the Krka National Park. The number of Gamasida individuals per sample ranged from 1.33 (Makarska) to 9.84 (Brač Island). In the gamasid community in the Krka National Park, the dominant species were Cheiroseius serratus $(D=26.6 \%)$, Rhodacarellus silesiacus $(D=12.3 \%)$, and Asca aphidioides $(D=8.92 \%)$. The studied mite communities on Brač Island were overwhelmed by Polyaspis patavinus $(D=44.11 \%), H y$ poaspis praesternalis $(D=13.43 \%)$, and $A$. nova $(D=8.21 \%)$. Near Makarska, the studied communities were dominated by Zercon fageticola $(D=23.15 \%)$, A. nova 
Table 1 . Indices of dominance ( $\mathrm{D}=\%$ of the total number of individuals) and constancy $(\mathrm{C}=\%$ of the total number of samples) of selected gamasid species, and characteristics of gamasid communities in the study sites in Croatia. The occurrence of other species is summarized in the footnote

\begin{tabular}{|c|c|c|c|c|c|c|}
\hline \multirow{2}{*}{ Species } & \multicolumn{2}{|c|}{ Brač Island (I) } & \multicolumn{2}{|c|}{ Krka NP (II) } & \multicolumn{2}{|c|}{ Makarska (III) } \\
\hline & $\mathrm{D}(\%)$ & $\mathrm{C}(\%)$ & $\mathrm{D}(\%)$ & $\mathrm{C}(\%)$ & $\mathrm{D}(\%)$ & $\mathrm{C}(\%)$ \\
\hline Evimirus uropodinus Berlese, 1903 & 0.00 & 0 & 1.24 & 9 & 0.00 & 0 \\
\hline $\begin{array}{l}\text { Pseudolaelaps paulseni (Berlese, } \\
\text { 1910) }\end{array}$ & 1.98 & 14 & 1.08 & 5 & 3.56 & 5 \\
\hline Asca aphidioides (Linnae, 1758) & 0.00 & 0 & 8.92 & 19 & 11.49 & 9 \\
\hline A. nova Willmann, 1939 & 8.21 & 23 & 0.00 & 0 & 16.92 & 12 \\
\hline Cheiroseius serratus (Halbert, 1915) & 0.74 & 2 & 26.60 & 31 & 0.57 & 1 \\
\hline Gamasellodes bicolor (Berlese, 1918) & 4.98 & 16 & 4.70 & 10 & 12.29 & 5 \\
\hline Hypoaspis kargi Costa, 1968 & 1.62 & 7 & 1.51 & 6 & 11.93 & 10 \\
\hline H. praesternalis Willmann, 1949 & 13.43 & 36 & 2.90 & 17 & 2.55 & 4 \\
\hline Polyaspis patavinus Berlese, 1881 & 44.11 & 24 & 0.00 & 0 & 0.00 & 0 \\
\hline $\begin{array}{l}\text { Rhodacarellus silesiacus Willmann, } \\
1936\end{array}$ & 0.26 & 2 & 12.30 & 26 & 0.54 & 1 \\
\hline Zercon athiasi Vincze, 1965 & 0.18 & 2 & 0.00 & 0 & 0.96 & 1 \\
\hline Z. berlesei Sellnick, 1958 & 1.04 & 3 & 0.19 & 1 & 0.00 & 0 \\
\hline Z. fageticola Halašková, 1969 & 0.00 & 0 & 0.00 & 0 & 23.15 & 20 \\
\hline $\begin{array}{l}\text { Total abundance (individuals per } \\
50 \mathrm{~cm}^{3} \text { ) }\end{array}$ & \multicolumn{2}{|c|}{9.84} & \multicolumn{2}{|c|}{8.30} & \multicolumn{2}{|c|}{1.33} \\
\hline Number of species & \multicolumn{2}{|c|}{25} & \multicolumn{2}{|c|}{33} & \multicolumn{2}{|c|}{25} \\
\hline Shannon index of diversity $\left(H^{\prime}\right)$ & \multicolumn{2}{|c|}{2.107} & \multicolumn{2}{|c|}{2.654} & \multicolumn{2}{|c|}{2.479} \\
\hline
\end{tabular}

Ascidae: Ascidae - II, Lasioseius fimetorum Karg, 1971 - II, Platyseius italicus (Berlese, 1905) - I, Proctolaelaps pygmaeus (Müller, 1860) - III, Protogamasellus primitivus Karg, 1962 - I, III, Zercoseius spathuliger (Leonardi, 1899) - I, Digamasellidae: Dendrolaelaps rectus Karg, 1962 - II, Dendrolaelaps sp. 1 - I, Dendrolaelaps sp. 2 - II, Eviphididae: Thinoseius kargi Hirschmann, 1966 - III, Laelapidae: Hypoaspis aculeifer (Canestrini, 1883) - I, II, III, Hypoaspis claviger (Berlese, 1883) - I, II, III, Hypoaspis cuneifer (Michael,1891) - I, Holostaspis montana (Berlese, 1904) - I, III, Hypoaspis vacua (Michael, 1891) - I, III, Hypoaspis sp. - III, Macrochelidae: Macrocheles scutatiformis Petrova, 1967 - II, Macrocheles scutatus (Berlese, 1904) - II, Pachylaelapidae: Olopachys scutatus Berlese, 1910 - III, Pachylaelaps pectinifer (G. et R. Canestrini, 1882) - II, Parasitidae: Paragamasus runciger (Berlese, 1903) - II, Paragamasus sp. - II, Parasitus hyalinus (Willmann, 1949) - I, Pergamasus crassipes (Linnae, 1758) - II, III, Pergamasus septentrionalis (Oudemans, 1902) - II, Pergamasus sp. - I, Phytoseiidae: Amblyseius obtusus (C. L. Koch, 1839) - II, Amblyseius sp. - I, III, Podocinidae: Podocinum pacificum Berlese, 1896 - II, Rhodacaridae: Rhodacarellus perspicuus Halašková, 1958 - I, Rhodacaropsis sp. - III, Trachytidae: Trachytes lambda Berlese,1903 - II, Trematuridae: Trichouropoda ovalis (C. L. Koch, 1839) - II, Urodinychidae: Dinychus inermis (C. L. Koch, 1841) - II, Urobovella vinicolora (Vitzthum, 1926) - II, Uropodidae: Uropoda minima Kramer, 1882 - II, Uropoda sp. - II, Uropodina: Uropodina 1 - II, Uopodina 2 - III, Veigaiidae: Veigaia cf. decurtata Athias-Henriot, 1961 - III, Veigaia exigua (Berlese, 1916) - I, III, Veigaia planicola (Berlese, 1892) - II, Zerconidae: Prozercon sp. - I, II, 
( $D=16.92 \%)$, Gamasellodes bicolor $(D=12.29 \%)$, Hypoaspis kargi $(D=11.93 \%)$, and A. aphidioides $(D=11.49 \%)$. The abundance of selected gamasid species was analysed within various microhabitats: $Z$. athiasi - Makarska (moss on soil, $A=0.03$; moss on tree trunks, $A=0.13$ ), Brač Island (moss on stones, $A=0.04$; litter, $A=0.04$ ); $Z$. fageticola - Makarska (moss on soil, $A=0.19$; moss on stones, $A=1.15$; moss on tree trunks, $A=0.87$; decaying wood, $A=0.04$; litter, $A=0.13$ ); $Z$. berlesei - Brač Island (litter, $A=0.22$ ), Krka NP (moss covering stones, $A=0.04$ ); Polyaspis patavinus - Brač Island (decaying wood in tamarisk hollows, $A=15.36$ ); Cheiroseius serratus - Krka NP (moss covering tree trunks, $A=15.11$; moss on soil, $A=2.43$; moss on stones, $A=1.75$ ), Makarska (moss on soil, $A=0.04$ ), Brač Island (litter, $A=0.15$ ); Asca nova - Makarska (moss on soil, $A=0.56$; moss on stones, $A=0.40$; moss on tree trunks, $A=0.27$ ), Brač Island (moss on stones, $A=0.61$; decaying wood, $A=0.05$; litter, $A=1.48)$; $A$. aphidioides - Krka NP (litter, $A=3.27$ ), Makarska (moss on soil, $A=0.14$; moss on stones, $A=0.82$; moss on tree trunks, $A=0.13$; decaying wood, $A=0.22$; litter, $A=0.40$ ).

\section{DISCUSSION}

The Balkan Peninsula, on account of the division between the Euro-Siberian and the Mediterranean regions, is an exceptionally interesting area for faunistic and zoogeographical studies. Current research on gamasid communities within that region concerned mostly the mites appearing on mammals and in their nests located in Bulgaria (KoJuMdZIJEva 1975a; 1975b; 1982; 1983; 1985; 1986a; 1986b), as well as the communities of Uropodina found in Greece or Bosnia and Herzegovina (Athias-Binche \& BŁoszyk 1985; Hirschmann \& Wiśniewski 1993). A thorough study of Croatian invertebrate fauna, including scorpions, pseudoscorpions, spiders, centipedes, millipedes, and mites, mainly of the Oribatida, was made by RUCNER \& RUCNER (1995). Another relatively well-documented mite group in Croatia are water mites (PESIC 2002).

Out of the dominant species within the study area, Cheiroseius serratus, Rhodacarellus silesiacus, Asca aphidioides, A. nova, Hypoaspis praesternalis, and Gamasellodes bicolor are widespread across the Holarctic. The occurrence of Polyaspis patavinus, Zercon fageticola and Hypoaspis kargi is limited to the Euro-Siberian region. Evimirus uropodinus is an interesting species recorded in the Krka National Park (both in the moss covering stones and in decaying wood). In spite of its wide range, it is mostly present at the southern verge of the Holarctic (in Italy, Georgia, Crimea, Korea, Japan and North America) (Bregetova et al. 1977; Ehara 1980; Farrier \& Hennessey 1993; Kaczmarek \& Lee 2000). In contrast, Pseudolaelaps paulseni belongs to the Mediterranean fauna and was not recorded before beyond Italy (BREGETOVA et al. 1977).

The zoogeographic distribution and ecological preferences of the most interesting species are described in detail below.

Zercon athiasi Vincze is a European xerophilic species observed in Poland, the Czech Republic, Slovakia, Austria, Hungary, and Ukraine. It is a mesotypic species 
found so far in various kinds of microhabitats. According to HALAŠKOvÁ (1969), it is an extremely xerophilic species found in fallen leaves, detritus, moss, on grassy and rocky xerothermic sites points (often alongside Juniperus communis), steppes and forest steppes, as well as oak-acacia and pure oak stands (HALAŠKOvÁ 1969; BŁASZAK 1974; Bregetova et al. 1977; MAšÁn \& Fenda 2004).

Zercon fageticola Halašková is a European species recorded in Poland, Austria, the Czech Republic as well as Slovakia, Latvia, and Ukraine. It is found in leaf litter in coniferous stands with a small addition of broad-leaved trees, thermophilous oak forests, and heterogeneous detritus. It does not avoid more humid places, either. Relatively high numbers of this species were recorded in beech stands, also those mixed with hornbeams, maples, oaks, limes, elms, ashes, birches, spruces, firs, and pines. It was less frequent in forests and on grassy slopes. It is probably a Carpathian species spreading its range across Central Europe (BŁAszAK 1974; BREGETOVA et al. 1977; Athias-HenRIOT 1981; MašÁn \& FENDA 2004).

Zercon berlesei Sellnick is a rare Mediterranean species observed so far in Poland, the Czech Republic, Slovakia, Hungary, Spain, Italy, Iceland, Great Britain, Romania, Bulgaria, and Turkey. It is one of the few gamasid species that have adapted to xerothermic vegetation, such as steppes, forest steppes, and thermophilous oak as well as oak-hornbeam forests. It is also found in psychrophilic alpine and subalpine habitats (e.g. Seslerion tatrae), spruce forests mixed with maples, in vegetation covering rock debris, communities consisting of Salix reticulata and Pinus mugo, lawns, mosses, detritus, and needle litter (BŁAszaK 1974; Bregetova et al. 1977; MašÁN $\&$ FENDA 2004).

Polyaspis patavinus Berlese is a European species observed as yet in Spain, Portugal, Belgium, France, Germany, Poland, Czech Republic, Slovakia, Austria, Hungary, Italy, and Armenia. It is found in decaying wood and compost (BregetovA et al. 1977; HirschMANN \& WiśnIEWSKi 1993).

Cheiroseius serratus (Halbert) is a Central- and North-European species. It is found in meadow soil, lawns, wet litter, spruce forests, mosses, and peat mosses. It favours clay soil and black earth (KARG 1993).

Asca nova Willmann is recorded in Western Europe and North America. It is found in the soil of fields and meadows, scarcely also in stands of broad-leaved and coniferous trees, in decaying litter and wood, humus, mosses, and lichens. This species favours moderately humid habitats (BREGETOVA et al. 1977; KARG 1993; FARRIER \& HENNESSEY 1993).

Asca aphidioides (Linnae) is observed in Western Europe and North America. It is scarce in the soil of fields (cereals) and meadows, but more frequent in broadleaved and mixed forests, humus, litter, mosses, lichens, decaying wood, under tree bark, as well as in rodent nests. It favours moderately humid places (RYKE 1961; Bregetova et al. 1977; FArrier \& HenNessey 1993; KARg 1993).

\section{CONCLUSIONS}

1. Overall, within 3 study sites in southern Croatia (Dalmatia), we recorded 56 species of the Gamasida, belonging to 32 genera. 
2. The genus Hypoaspis was represented by as many as 8 species, while the genera Pergamasus, Veigaia and Zercon, by 3 species each.

3. Zercon fageticola, Asca nova (Makarska), Cheiroseius serratus (Krka National Park), and Polyaspis patavinus (Brač Island) reached high levels of dominance.

4. Zercon athiasi and Cheiroseius serratus favoured moss covering tree trunks, Zercon berlesei, Asca nova and A. aphidioides settled in litter, Zercon fageticola was recorded in moss patches on stones and tree trunks, and Polyaspis patavinus was found exclusively in decaying wood in tamarisk hollows.

5. Pseudolaelaps paulseni is the only Mediterranean species in the Croatian gamasid fauna. Other species are typical components of Euro-Siberian fauna. The range of Evimirus uropodinus mostly covers the southern verge of the Holarctic.

\section{REFERENCES}

Athias-Bınche F., BŁoszyK J. 1985. Crinitodiscus beieri Sellnick and Orientidiscus n. subgen. from the eastern Mediterranean region, with description of two new species and biogeographical remarks (Anactinotrichida: Uropodina). Acarologia, Paris, 26: 321-334.

Athias-Henriot C. 1981. Über die subalpinen und alpinen Pedogamnu-Bestände (Parasitiformes, Gamasida) des Glocknergebietes (Hohe Tauern, Österreich) [Subalpine and alpine Pedogamnu-populations (Parasitiformes, Gamasida) of the Grossglockner region (Hohe Tauern, Austria)], Veröffentlichungen des Österr. MaßHochgebirgsprogramms Hohe Tauern, 4: 95-100 (In German).

BŁaszaK C. 1974. Zerconidae (Acari, Mesostigmata) Polski. Monografie Fauny Polski 3, PWN Warszawa, Kraków, 315p.

BREGETOVA I. G. 1977. Opredelitel obitayushchikh w pochve kleshchei [Identification key to soilinhabiting mites Mesostigmata]., AN SSSR, Leningrad. 718 p (In Russian).

Ehara S. 1980. Illustrations of the mites and ticks of Japan. Zenkoku Noson Kyoiku Kyokai.

FarRier M. H., HenNessey M. K. 1993. Soil-Inhabiting and free living Mesostigmata (Acari, Parasitiformes) from North America. Tech. Bull. 302: 1-410.

HaLAŠKovÁ V. 1969. Zerconidae of Czechoslovakia (Acari, Mesostigmata). Acta Univ. Carolinae - Biol., Praha. 3-4:175-352

Hirschmann W., WiśnIewski J. 1993. Die Uropodiden der Erde. Acari Parasitiformes. Supercohors Atrichopygidiina, Hirschmann 1975 [Uropodina of the World. Acari, Parasitiformes, Supercohort: Atrichopygidiina, Hirschmann 1975], Acarologie Schrriftenreihe für vergleichende Milbenkunde. Hirschman Verlag. Folge 40. 466 p (In German).

Kaczmarek S., Lee J. H. 2000. Gamasida (Acari) in the some forest habitats in South Korea. Acta zool., cracov. 43: 293-302.

KARG W. 1993. Acari (Acarina), Milben Parasitiformes (Anactinochaeta) Cohors Gamasina Leach. Raubmilben [Predatory mites, Acari (Acarina), Parasitiformes (Anactinochaeta) Cohors Gamasina Leach.] Die Tierwelt Deutschlands 59: 1-523 (In German).

KoJumdziseva M. 1975a. A contribution to the fauna of mites in the Gamasoidea (Parasitiformes) in Bulgaria. Acta zool., Bulgarica, Sofia. 1: 85-87.

KoJumDziJeva M. 1975b. Mites of the families Parasitidae and Macrochelidae (Gamasoidea, Parasitiformes) inhabiting the Dung in the vacinity of Sofia. Acta zool., Bulgarica, Sofia. 2: 91-95.

KoJumdziseva M. 1982. The gamasoid mites (Gamasoidea, Parasitiformes) from the Wrack on the Bulgarian Black Sea coast. Acta zool., Bulgarica, Sofia. 20: 77-80. 
Kojumdziseva M. 1983. Free-Living and insecticolous mites (Mesostigmata) from Rhodops Mountains. Acta zool., Bulgarica, Sofia. 23: 19-24.

KoJumDZIJeva M. 1985. Species composition and population dynamics of mites (Gamasina, Mesostigmata and Acaridiae, Astigmata) in a Dunghill. Acta zool., Bulgarica, Sofia. 28: 17-27.

KoJumdzIJeva M. 1986a. Free-Living gamasoid mites (Gamasoidea, Parasitiformes) from the Danubian Plain. Acta zool., Bulgarica, Sofia. 30: 36-43.

KoJumdziseva M. 1986b. Gamasoid mites (Gamasoidea, Parasitoformes) from southwest Bulgaria. Fauna of Southwestern Bulgaria, Bulg. Ac. Sci, Sofia, Part 1: 149-158.

MašÁn P., Fenda P. 2004. Zerconid mites of Slovakia (Acari, Mesostigmata, Zerconidae). Institute of Zoology, Slovak Academy of Sciences, Bratislava. 238p.

Pesic V. M. 2002. New records of water-mites (Acar, Hydrachnidia) based on the material collected by T. Petkovski in Croatia, including a check-list of species recorded in Croatia. Nat. Croat. Zagreb. 11: 447-453.

RuCNER D., RuCner R. 1995. Contribution to the knowledge of some Arthropoda (Scorpiones, Pseudoscorpiones, Araneae, Acari, Diplopoda and Chilopoda) in forest communities of Croatia. Nat. Croat. Zagreb. 4: 185-225.

RYKE P. A. J. 1961. A review of the genus Asca von Heyden with descriptions of new species (Acarina; Mesostigmata; Rhodacaridae). Zoologischer Anzeiger 167: 127-135. 